\title{
ELECTROENCEPHALOGRAM BASE RHYTHM IN AIDS PATIENTS
}

\author{
G. FERNANDES DO PRADO *, A. BAPTISTA DA SILVA **, J.G. CAMARGO LIMA ***
}

SUMMARY - We studied the EEG of 73 patients diagnosed with HIV infection, with or without secondary complications. Sixty-eight belonged to CDC (Center for Disease Control) group IV and 38 presented signs or symptoms of encephalic neurological impairment. Rhytms constituting base activity were alpha (65.75\%), beta (13.70\%), theta (12.33\%), and delta (8.22\%). The alpha rhythm presented two modes: slow (8 to $9 \mathrm{~Hz}$ ) in 25/48 or 52.08\% of the cases and not-slow $(>9$ to $13 \mathrm{~Hz}$ ) in $23 / 48$ or $47.92 \%$ of the cases. The alpha slow-mode has been observed in about 10 to $15 \%$ of the normal population, with the $8 \mathrm{~Hz}$ frequency being found in only $1 \%$ of the normal adult population, which suggests that in some manner HIV is implicated in the slowing-down of the EEG base rhythm in AIDS patients. The patients from CDC group IV with encephalic neurological involvement presented a base rhythm significantly lower than those with non-encephalic involvement or the absence of neurologicai impairment.

KEY WORDS: AIDS, EEG, HIV infection, background activity.

\section{Ritmo de base no eletrencefalograma de pacientes aidéticos}

RESUMO - Estudamos o EEG de 73 pacientes com diagnóstico de infecção pelo HIV, com ou sem complicações secundárias. Sessenta e oito deles pertenciam ao grupo IV de CDC (Center for Disease Control) e 38 apresentavam sinais ou sintomas de comprometimento encefálico. Os ritmos que constituiram a atividade de base foram o alfa $(65,75 \%)$, o beta (13,70\%), teta $(12,33 \%)$ e o delta $(8,22 \%)$. O ritmo alfa apresentou duas modalidades: a lenta (8 a 9Hz) em 25/48 ou 52,08\% dos casos e a não-lenta ( $>9$ a $13 \mathrm{~Hz}$ ) em $23 / 48$ ou $47,92 \%$ dos casos. A modaidade lenta do ritmo alfa é observada em cerca de 10 a $15 \%$ da populaçào normal, sendo a frequência de $8 \mathrm{~Hz}$ encontrada em apenas $1 \%$ da população adulta normal, o que sugere que o HIV de alguma maneira está implicado na lentificação do ritmo de base no EEG de placientes aidéticos. Os pacientes do grupo IV do CDC com envolvimento neurológico encefálico apresentaram ritmo de base significantemente menor que aqueles com envolvimento neurológico não encefálico ou ausência de comprometimento neurológico.

PALAVRAS-CHAVE: AIDS (SIDA), EEG, infecção por HIV, ritmo de base.

AIDS (acquired immunodeficiency syndrome) was described in 19813 . It acquired epidemic proportions, causing thousands of victims, and is caused by a virus known as HIV (human immunodeficiency virus) which infects CD4 + cells such as the lymphocytes and macrophages. The macrophages are resistant to te virus' cytopathic effects, becoming their vehicles at the nervous system level - the Trojan horse hypothesis 16. AIDS is classified in four groups: (I) acute infection, (II) asymptomatic infection, (III) persistent generalized lympha. denopathy, and (IV) other signs and symptoms arising from HIV infection 4.

The EEG of the AIDS patients was studied in 1985 by Enzensberger. He, and other authors, observed that the slowing-down of base activity was the most

*Post Graduate Student in Neurology, Escola Plaulista de Medicina (EPM); **Adjunct Professor of Neurology, Head of the EEG and Polysomnography Sector, EPM; ***Full Professor and Head of the Discipline of Neurology, EPM. Aceite: 28-Outubro-1992.

Dr. Gilmar Fernandes do Prado - Rua Santa Flora 244 - 01549-040 São Paulo SP - Brasil. 
important and frequent alteration, found principally in CDC group IV and in patients with the so-called AIDS demential complex 5,9,19. Since the first EEG studies in AIDS patients, it has been accepted that this slowing-down of the base rhythm arose from direct action by the virus on the nervous system. The studies in which the patients with secondary complications (infections, neopla. sias, metabolic alterations, and others) were excluded also permitted the same conclusion 12,14.

\section{MATERIAL AND METHOD}

We conducted EEGs on 73 patients diagnesed with HIV infection. Sixty-eight of them belcnged to CDC group IV, one to group III, and four to group II. Patients with and without secondary complications were inciuded. The minimum age was 11 years old; the maximum, 57; and the median was 32.8 years old ( $\mathrm{SD}=8.9$ years). Neurological evaluation included the clinical exam and cerebrospinal fluid (CSF) of all patients and computerized tomography of the cranium of nine.

The BHEG was conducted with Berger Model TP 119 and Meditron equipment according to International criteria, using the 10-20 system for marking the head, $0.3 s$ time constant, $3 \mathrm{cmm} / \mathrm{s}$ paper velocity and an increase of $50 \mathrm{microvolt} / 5 \mathrm{~mm}$ in the deflection of the pins.

The neurological evaluation permitted classification of these patients into three groups: (A) with "encephalic involvement" (signs and/or symptoms of telencephalic or cerebral trunk impairment; 38 patients); (B) with "nonencephalic involvement" (signs and/or symptoms of impairment of the spinal cord and/or periphertal nerves; 16 patients); and (C) with "absence of neurological involvement" (patients in whom clinical signs of encephalic, spinal cord or peripheral nerves impairment were not observed; 19 patients).

Base activity was measured visually with a millimetric ruler, choosing the areas of greatest expression of this rhythm for gauging its frequency. When this rhythm showed variation in frequency during the examination, we considered the highest value. When the base rhythm was formed by the alpha rhythm, it was divided into slow alpha (8-9 Hz) and not-slow alpha $(>9 \mathrm{~Hz}) 5$.

We compared the distribution of the base rhythm in groups $\mathbf{A}, \mathbf{B}$, and $\mathbf{C}$, as well as group $A$ with groups $B$ and $C$ combined into one group.

In the 38 patients with encephalic involvement, we excluded those showing one or more secondary complications 7, fast EEG rhythms 5 and those with convulsive crises and mental confusion 5; the base rhythm of the EWGs of the 21 remaining patients were compared, and for them diagnoses were: neurocryptococcosis (NC), 10 patients; cerebral toxoplasmosis (CT), 7 patients; and demential syndrome (DS), 4 patients.

The following statistical tests were applied: (1) analysis of the variation of KruskalWallis posts in order to compare the base rhythm according to the groups with neurological involvement and in order to compare the base rhythm according to the groups with diseases that provoked encephalic involvement; (2) Mann-Whitney test with approximation to the normal curve in order to compare the groups with neurological involvement.

\section{RESULTS}

Analysis of the base rhythm of 73 patients allowed us to observe that alpha rhythm was present in 48 patients (65.75\%). Betha rhythm was observed in 10 patieents (13.70\%), theta rhythm in $9(12.33 \%)$, and delta rhythm in 6 patients $(8.22 \%)$.

In the 48 patients with alpha rhythm in the base activity, 25 (52.08\%) showed slow alpha and $23(47.92 \%)$ presented alpha greater than $9 \mathrm{~Hz}$. The average frequency of alpha in the 48 patients was $9.7 \mathrm{~Hz}$. We had 40 (54.79\%) abnormal, 17 (23.29\%) borderline (with sligth nonspecific and non-lateralized abnormalities, and/or slow alpha 5,9, and 16 (21.92\%) normal EEGs. 
Patients in group A showed a significantly lower base rhythm than those in group C (Table 1). Patients in group $A$ showed a significantly lower base rhythm than those in groups $B$ and $C$ combined (Table 2).

The base rhythm in 21 patients with encephalic involvement due to cerebral toxoplasmosis, demential syndrome, and neurocryptococcosis were not significantly different when these three groups were compared (Table 3 ).

Table 1. Distribution of base rhythm according to groups $\mathbf{A}, \mathbf{B}$ and $\mathbf{C}$.

\begin{tabular}{|c|c|c|c|c|}
\hline & \multicolumn{2}{|c|}{$\mathbf{A}$} & \multirow{2}{*}{$\begin{array}{l}\text { B } \\
\underline{9}\end{array}$} & \multirow{2}{*}{$\frac{\mathrm{C}}{14}$} \\
\hline & 2 & 14 & & \\
\hline & 14 & 8 & 14 & 12 \\
\hline & 8 & 9 & 11 & 8 \\
\hline & 8 & 10 & 8 & 14 \\
\hline & 7.5 & 9 & 8 & 8 \\
\hline & 5 & 11 & 8 & 11 \\
\hline & 7 & 10 & 12 & 9 \\
\hline & 11 & 3.5 & 9 & 14 \\
\hline & 10.5 & 10 & 6 & 8 \\
\hline & 6 & 7.5 & 10 & 12 \\
\hline & 7 & 3 & 8 & 9 \\
\hline & 14 & 10 & 10 & 12 \\
\hline & 7.5 & 14 & 9 & 9 \\
\hline & 8.5 & 10 & 10 & $y$ \\
\hline & 9 & 2 & 14 & 12 \\
\hline & 8 & 12 & 11 & 11 \\
\hline & 3 & 10 & 2 & 11 \\
\hline & 8 & 14 & & 9 \\
\hline & 10 & 7 & & \\
\hline M & & & 37.50 & 46.89 \\
\hline $\mathrm{R}$ & & & 637.50 & 844.00 \\
\hline
\end{tabular}

A, incephaic involvement; B, non-encephalic involvement; $C$, absence of neurological invoivement; iM, mean position; $R$, sum of positions.

Analysis of variance by Kruskal-Wallis-Position: H critical $=5.99$; H calculated $=6.04 \%$. The groups differ significantly.

Lunn Test:

$\begin{array}{lcc}\text { Pairs } & \text { AVDBPA1 } & \text { MSD2 } \\ \text { AB. } & 5.41 & 14.80 \\ \text { AC } & 14.80^{*} & 14.51 \\ \text { BC } & 9.39 & 17.15\end{array}$

Groups $\mathbf{A}$ and $\mathbf{C}$ differ significantly.

I Absolute value of difference between position averages; 2 Minimal significant difference. 
Table 2. Distribution of base rhythm according to groups $A$ and $B+C$.

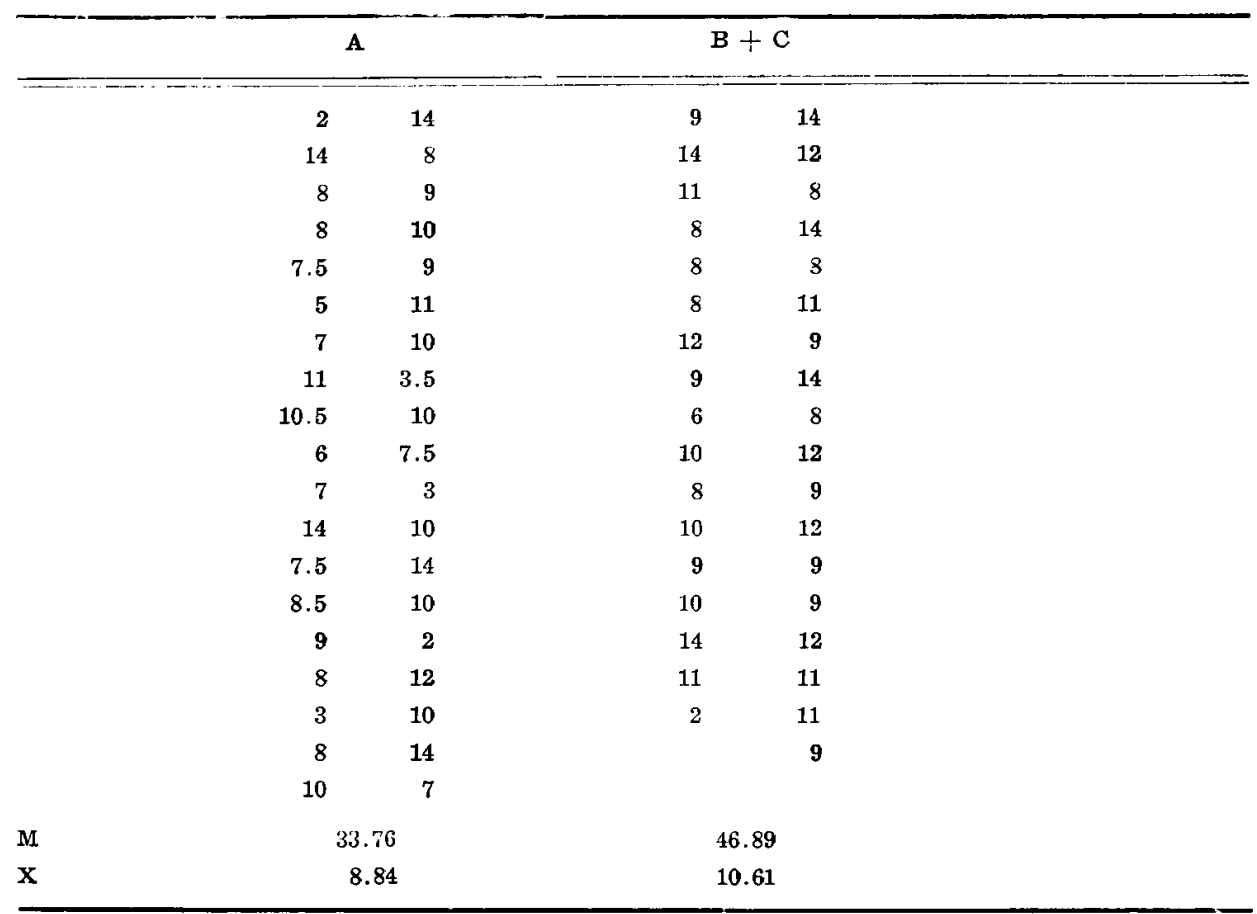

A, encephalic involvement; $B+C$, combining of groups with non-encephalic neurological involvement; $\mathrm{N}$, mean position; $\mathrm{X}$, sum of positions..

Mann-Whitney Test with approximation to normal curve: $Z$ critical $=1.96 ; Z$ calculated $=2.2 \mathrm{~s}^{*}$. The values of the frequencies of base rhythm are significantly greater in the group $\mathbf{B}+\mathrm{C}$.

Table 3. Study of base rhythms related to groups with cerebral toxoplasmosis (CT), demential syndrome (DS), and neurocryptococosis (NC).

\begin{tabular}{rrrr} 
& & Groups & \\
& TC & SD & NC \\
& 8 & 10 & 9 \\
& 7 & 8 & 8 \\
& 11 & 7 & 10 \\
& 8.5 & 7.5 & 3 \\
& 9 & 8 & \\
& 11 & 7.5 & \\
& 10 & 12 & \\
& 7 & & \\
& 9 & & 9.75 \\
M & 10 & 9.79 & 39.00 \\
\hline
\end{tabular}

M, mean position; $R$, sum of positions.

Analysis of variance by Kruskal-Wallis Position: $\mathrm{H}$ critical $=5.99 ; \mathrm{H}$ calculated $=0.90$. The groups do not differ significantly. 


\section{COMMMENTS}

Knowledge of how EEG base rhythms behave in AIDS patients with or without neurological impairment is useful to the electroencephalographist, in spite of the multiple factors susceptible to modifying them in a heterogeneous population, where we observed from asymptomatic patients to those with acute secondary complications: opportunistic infections, metabolic disturbances, encephalitis, meningoencephalitis, convulsions, and other pathologies 1,8,10,11,17.

In spite of the various affections to which those patients can be submitted, alpha rhythm was present in $48(65.75 \%)$ and fast rhythms in $10(13.70 \%)$.

Considering the EEGs in terms of base activity, there should have been only $15(20.55 \%)$ abnormal exams according to this criteria. In our sample there were 40 abnormal EEGs, the presence of asymmetries and abnormal paroxysmal activities being other causes of abnormality.

Upon making more detailed observations of the frequencies of the base rhythms in those patients having it formed by the alpha rhythm, we observed that it can be divided into two classes: one called slow alpha, with frequencies ranging from 8 to $9 \mathrm{~Hz}$ (inclusive), and another called not-slow alpha, with frequencies greater than $9 \mathrm{~Hz}$ (up to $13 \mathrm{~Hz}$ ).

Slow alpha was present in 25/48 EEGs $(52.08 \%$ ) with alpha in the base activity. Enzensberger, studying 26 AIDS patients, observed slow alpha in 13 $(50 \%)$ of them, which is frequently confirmed by all authors who have studied EEG in AIDS patients, including when patients with AIDS-related complications are excluded $2,5,15,18$. These EEGs showing alpha rhythm, an expressive portion of those patients' EEGs, have been referred to as borderline or slightly abnormal by some authors 9,19 . We believe it is reasonable to refer to them as borderline, though in our classification of AIDS patients' EEGs 6,7 they have been classified among those presenting degree I of diffuse encephalopathy.

Theta and delta rhythms are more common in CDC groups III and IV, mainly in the final phases of the AIDS demential complex 15 .

The base rhythm frequency was significantly lower in the group with encephalic involvement in our sample, a fact also referred to by other authors $\mathbf{5 , 8 , 9}$, suggesting that this occurs due to secondary metabolic alterations to systemic impairment 13 and to metabolic alterations related to subproducts of viral replication 16. Patients in group B and $C$, when combined, show base rhythms significantly different in relation to group A, having concordance between the neurological exam and the EEG in the detection of encephalic involvement.

There was no significant difference among the base rhythms of the groups with toxoplasmosis, neurocryptococcosis, and demential syndrome. In spite of the small number of patients studied according to this criteria, it was observed that the patients with cerebral toxoplasmosis showed a base rhythm frequency discretely higher than patients with demential syndrome.

\section{REFERENCES}

1. Anders KH, Guerra WF, Tomlyasu U, Verity MA, Vinters AV. The neuropathology of AIDS: UCLA experience and review, Am J Pathol 1986, 124:537-558.

2. Belman LA, Ultmann MH, Horoupian D, Novick B, Spiro AJ, Rubinstein A, Kurtzberg D, Conewesson B. Neurological complications in infants and children with acquired immune deficiency syndrome. Ann Neurol 1985, 18:560-566.

3. CDC, Center for Disease Control. Pneumocystis pneumonia. MMWR 1981, 30:250-252.

4. CDC, Center for Disease Control. Classification system for human T-lymphotropic virus type III/lymphadenopathy-associated virus infections. MMWR 1986, 35:334-339.

5. Enzensberger W, Fischer PA, Helm EB, stille W. Value of electroencephalography in AIDS. Lancet 1985, 4:1047-1048.

6. Fernandes do Prado G, Silva AB, Acceturi CA. EEG Classification of AIDS. In XII International Congress of Electroencephalography and Clinical Neurophysiology. Abstracts. Rio de Janeiro, 1990, p 28. 
7. Fernandes do Prado G. Estudo das alterações eletrencefalográficas em pacientes aidéticos com ou sem complicaçóes secundárias. Tese de Mestrado, Escola Paulista de Medicina São Paulo, 1991.

8. Fischer PA, Enzensberger W. Neurological complications in AIDS. J Neurol 1987, 234: 269-279.

9. Gabuzda DH, Levy SR, Chappa KH. Electroencephalography in AIDS and AIDs-related complex. Clin Electroenceph 1988, 19:1-6.

10. Gray F, Gherardi $R$, Poirier J. Les lésions du système nerveux au cours du SIDA. Arch anat cytol path 1986, $34: 268-278$.

11. Levy RM, Bredesen DF, Rosenblun ML. Neurological manifestations of the acquired immunodeficiency syndrome (AIDS): experience at UCSF and review of the literature. J Neurosurg 1985, 62:475-495.

12. Minoli L, Nappi G. EEG findings and cognitive performance in 82 HIV-infected patients. Ve Conférence Internationale sur le SIDA (Le defi scientifique et social. Abrégés. Montreal, 1989, p 462 .

13. Navia BA, Jordan BD, Price RW. The AIDS dementia complex: I. Clinical features. Ann Neurol 1986, 19:525-535.

14. Norcrosf-Nechay $\mathbf{K}$, Borucki MJ, Borucki SJ, Pollard RB. FiEG background slowing appears in HIV-infected patients in the absence of metabolic derangements or other cerebral involvement. Ve Conférence Internationale sur le SIDA (Le defi scientifique et social. Abrégés. Montreal, 1989, p 461.

15. Parisi A, Di Perri G, Stosselli $M$, Minoli $L$. Testing for neurological involvement in HIV infection. Lancet 1989, 2:1531-1532.

16. Price R.W, Brew B, Sidtis J, Roseblum M, Scheck AC, Cleary P. The brtain in AIDS: central nervous system HIV-1 infection and AIDS dementia complex. Science 1988, 239: 586-591.

17. Sharbrough FW. Nonspecific abnormal EEG patterns. In Niedermeyer EL, Lopes da Silva F (eds): Electroencephalography (basic principles, clinical applications and related fields). Ed 8. Baltimore: Urban \& Schwarzenberg 1987, p 163-181.

18. Schnurbus $R$, Henkes $H$, Scheuler W, Haay C, Au FV, Bienzle U, Friedrich-Jaanicke B, Hoffmann HG, Kubicki ST. EEG findings with the HIV infection. Clin Neurol Neurosurg 1987, 89:94.

19. Tinuper P, De Carolis P, Galeotti M, Baldrati A, Sacquegna TL, Gritti FM. Electroencephalography and HIV infection. Lancet 1989, 1:554. 